\title{
PREPARATION AND DIELECTRIC PROPERTIES OF THERMO-VAPOROUS $\mathrm{BaTiO}_{3}$ CERAMICS
}

\author{
PRIPRAVA IN DIELEKTRIČNE LASTNOSTI TERMO-PARNO \\ POROZNE KERAMIKE $\mathrm{BaTiO}_{3}$
}

\author{
Anastasia Kholodkova1, Marina Danchevskaya1, Nellya Popova², \\ Liana Pavlyukova ${ }^{2}$, Alexandr Fionov ${ }^{3}$ \\ ${ }^{1}$ Chemistry Department, Moscow State University, GSP-1, Leninskie Gory 1-3, 119991 Moscow, Russia \\ ${ }^{2}$ D. Mendeleev University of Chemical Technology of Russia, Geroev Panfilovtsev 20, 125047 Moscow, Russia \\ ${ }^{3}$ Kotel'nikov Institute of Radio Engineering and Electronics of RAS, Mokhovaya 11-7, 125009 Moscow, Russia \\ anastasia.kholodkova@gmail.com
}

Prejem rokopisa - received: 2013-11-10; sprejem za objavo - accepted for publication: 2014-07-17

doi:10.17222/mit.2013.276

\begin{abstract}
A crystalline $\mathrm{BaTiO}_{3}$ powder was synthesized at $350{ }^{\circ} \mathrm{C}$ for $0-20 \mathrm{~h}$ from $\mathrm{TiO}_{2}(>99 \%$ purity) and $\mathrm{BaO}(>98 \%$ purity) with water vapour acting as the reaction media. According to the XRD and SEM results, the $\mathrm{BaTiO}_{3}$ synthesized for $3 \mathrm{~h}$ proved to be the most adequate raw material for ferroelectric ceramics among the obtained samples as long as it consisted of pure crystalline sphere-shaped $\mathrm{BaTiO}_{3}$ particles with the average size of $156 \mathrm{~nm}$. Pellets were pressed at $(100,150$ and 200) MPa and sintered at $1300{ }^{\circ} \mathrm{C}$ for $1 \mathrm{~h}$. The influence of the compacting pressure on the dielectric characteristics of $\mathrm{BaTiO}_{3}$ ceramics was studied by monitoring the permittivity and loss-tangent values of the pellets at $20 \mathrm{~Hz}-2 \mathrm{MHz}$.

Keywords: barium titanate, thermo-vaporous synthesis, microstructure, dielectric ceramics
\end{abstract}

Kristalni prah $\mathrm{BaTiO}_{3}$ je bil sintetiziran pri $350{ }^{\circ} \mathrm{C}$ od 0 do $20 \mathrm{~h}$ iz $\mathrm{TiO}_{2}$ (čistost: > $99 \%$ ) in $\mathrm{BaO}$ (čistost: > $98 \%$ ) z vodno paro kot reakcijski medij. Iz rentgenogramov in SEM-posnetkov izhaja, da je $\mathrm{BaTiO}_{3}$, sintetiziran 3 h, najprimernejša surovina med vsemi vzorci za feroelektrično keramiko, dokler sestoji iz čistih kristalnih okroglih delcev $\mathrm{BaTiO}_{3} \mathrm{~s}_{\text {povprečno velikostjo } 156}$ $\mathrm{nm}$. Peleti so bili stiskani pri $\left(100,150\right.$ in 200) MPa in sintrani $1 \mathrm{~h}$ pri temperaturi $1300{ }^{\circ} \mathrm{C}$. Vpliv tlaka pri stiskanju na dielektrične lastnosti keramike $\mathrm{BaTiO}_{3}$ je bil preiskovana s spremljanjem permitivnosti in velikosti izgube tg $\delta$ peletov pri 20 $\mathrm{Hz}-2 \mathrm{MHz}$.

Ključne besede: barijev titanat, termo-parno porozna sinteza, mikrostruktura, dielektrična keramika

\section{INTRODUCTION}

Since the 1940s barium titanate, $\mathrm{BaTiO}_{3}$, has been known for its extremely high values of ferroelectric characteristics which make it widely used in the production of multilayer ceramic capacitors (MLCCs), resistors with a positive temperature coefficient of resistivity (PTCR), temperature/humidity/gas sensors, piezoelectric transducers and actuators, ultrasonic and electro-optic devices, IR-detectors, etc. ${ }^{1-4}$ Generally, the $\mathrm{BaTiO}_{3}$ powder is obtained as the raw material for the bulk-ceramic manufacturing, as well as thin-film and composite-material production. ${ }^{4}$ For this purpose a homogeneous, well-dispersed pure $\mathrm{BaTiO}_{3}$ powder, consisting of spherical particles up to $200 \mathrm{~nm}$ in size, is required. ${ }^{1,5,6}$ Various synthesis routes for the as-characterized powder have been developed over several decades. In addition to the conventional solid-state method, the techniques such as pyrolysis (Pechini, citrate processes), dispersion (catecholate synthesis, spray pyrolysis, sol-gel), precipitation (oxalate, hydrothermal and solvothermal synthesis) are widely used for the fine-crystalline $\mathrm{BaTiO}_{3}$ processing. ${ }^{1,7-14}$ But, as some of them are multistage and require the use of auxiliary substances, mostly in the solid state, hydrothermal and oxalate techniques are industrially suitable. The development of a simple and low-cost method for the industrial $\mathrm{BaTiO}_{3}$ production remains to be a pending problem.

In the present work water vapour at $350{ }^{\circ} \mathrm{C}$ was used as the medium for a $\mathrm{BaTiO}_{3}$ synthesis from simple oxides. A similar technique combined with the treatment in supercritical water fluid was previously successfully used for the production of $\mathrm{MgAl}_{2} \mathrm{O}_{4}, \mathrm{ZnAl}_{2} \mathrm{O}_{4}, \mathrm{Y}_{3} \mathrm{Al}_{5} \mathrm{O}_{12}$, $\mathrm{BaFe}_{12} \mathrm{O}_{19}, \mathrm{LiNbO}_{3}{ }^{15,16}$ and also $\mathrm{BaTiO}_{3} \cdot{ }^{17,18}$ As ceramic manufacturing is one of the main application areas for the $\mathrm{BaTiO}_{3}$ powder, steps were taken to develop this technique for obtaining the $\mathrm{BaTiO}_{3}$ with the thermovaporous process. We prepared ceramic samples in the same conditions, but varied the compressing pressure and studied the phase content, the microstructure and dielectric properties of the pellets in order to determine the most appropriate value of the pressure for the ceramic-manufacturing route.

\section{EXPERIMENTAL WORK}

The synthesis of $\mathrm{BaTiO}_{3}$ was performed in laboratory stainless-steel autoclaves using $\mathrm{BaO}(>98 \%$ purity) and $\mathrm{TiO}_{2}(>99 \%$ purity) as the starting reagents. As $\mathrm{BaO}$ 
interacts with $\mathrm{CO}_{2}$ in the air, forming $\mathrm{BaCO}_{3}$, in order to avoid a lack of $\mathrm{Ba}^{2+}$ ions in the reaction mixture, an amount fraction of excess of $\mathrm{BaO} 5 \%$ was used. After a thorough mixing by means of grinding in an agate mortar with a pestle, the reagents were placed into a special container inside the autoclave, separated from the distilled water. Hermetically closed autoclaves were heated up to $350{ }^{\circ} \mathrm{C}$ (the water-vapour pressure of 16 $\mathrm{MPa})$, kept at this temperature for $(0,0.5,1,2,3,4,5$, 20) $h$ and then cooled so that the water vapour condensed at the bottom of the autoclaves separated from the product. The product was first washed with acetic acid solution to avoid $\mathrm{BaCO}_{3}$ contamination and then with distilled water.

To produce a ceramic powder, the sample synthesized for $3 \mathrm{~h}$ (named BT-3h) was mixed with $1 \%$ PVA and uniaxially pressed into pellets at (100, 150 and 200) $\mathrm{MPa}$ at room temperature. The pellets were sintered at 1300 ${ }^{\circ} \mathrm{C}$ for $1 \mathrm{~h}$.

The phase contents of the powders and ceramics were identified with an X-ray diffraction analysis (STOE STADI P) using the $\mathrm{Cu}-K \alpha$ radiation in a range of $20^{\circ} \leq$ $2 \theta \leq 80^{\circ}$. The crystallite size was calculated with the Scherrer equation. The morphologies of the powder and ceramic samples were studied with scanning electron microscopy (JSM-6390 LA). The dielectric permittivity and loss tangent of the pellets were calculated from the capacity and the conductivity, respectively, of the plane condenser, in which each pellet was used as a dielectric layer. Dielectric characteristics were obtained with a precision LCR meter Agilent E4980a with a frequency range of $20 \mathrm{~Hz}-2 \mathrm{MHz}$.

\section{RESULTS AND DISCUSSION}

During the thermo-vaporous $\mathrm{BaTiO}_{3}$ synthesis, $\mathrm{H}_{2} \mathrm{O}$ molecules from the vapour became incorporated into the

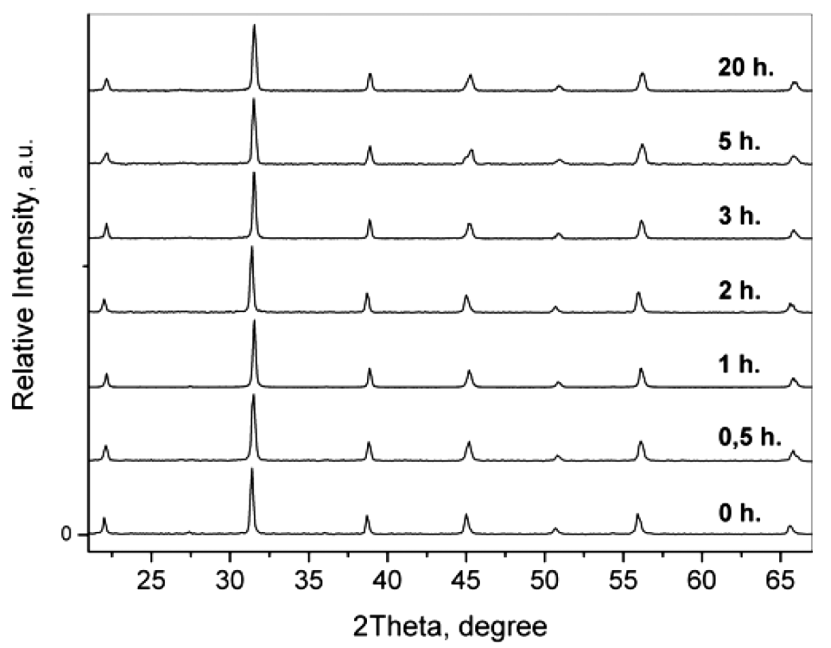

Figure 1: XRD patterns of the $\mathrm{BaTiO}_{3}$ powders synthesized in water vapour at $350{ }^{\circ} \mathrm{C}$ and $16 \mathrm{MPa}$ for $0-20 \mathrm{~h}$

Slika 1: Rentgenogram prahov $\mathrm{BaTiO}_{3}$ sintetiziranih od 0 do 20 ur, v vodni pari pri $350{ }^{\circ} \mathrm{C}$ in $16 \mathrm{MPa}$

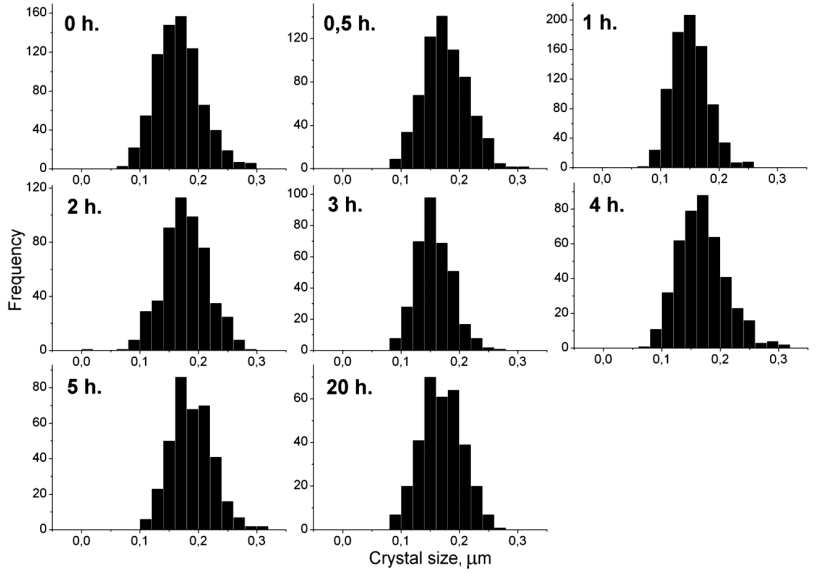

Figure 2: Crystal-size distributions of $\mathrm{BaTiO}_{3}$ synthesized in water vapour at $350{ }^{\circ} \mathrm{C}$ and $16 \mathrm{MPa}$ for $0-20 \mathrm{~h}$

Slika 2: Razporeditev velikosti kristalov $\mathrm{BaTiO}_{3}$, sintetiziranih od 0 do 20 ur, v vodni pari pri $350{ }^{\circ} \mathrm{C}$ in $16 \mathrm{MPa}$

$\mathrm{TiO}_{2}$ structure due to the dissociative absorption manifested in the breaking of the Ti-O bonds and the creation of the Ti-OH bonds. In these conditions the $\mathrm{TiO}_{2}$ structure becomes more flexible, interacting with the $\mathrm{Ba}^{2+}$ ions and reorganising into $\mathrm{BaTiO}_{3}$. The XRD analysis of the powders prepared at $350{ }^{\circ} \mathrm{C}$ in the water-vapour atmosphere over the periods of $0-20 \mathrm{~h}$ showed that the powders consisted of crystalline $\mathrm{BaTiO}_{3}$ (Figure 1). The formation of $\mathrm{BaTiO}_{3}$ from $\mathrm{TiO}_{2}$ and $\mathrm{Ba}(\mathrm{OH})_{2}$ occurred already during the heating, thus, the sample synthesized for $0 \mathrm{~h}$ contained only crystalline $\mathrm{BaTiO}_{3}$. The interaction of the newly formed $\mathrm{BaTiO}_{3}$ phase with water vapour led to an elimination of lattice defects and to a perfection of the crystalline structure. Figure 2 shows the $\mathrm{BaTiO}_{3}$ crystallite-size dependence on the duration of the thermo-vaporous synthesis, calculated from the Scherrer equation. The crystallite size of the samples synthesized for 0-4 h fluctuates in a range of 35-45 $\mathrm{nm}$, while, in the case of a longer synthesis, the crystallite

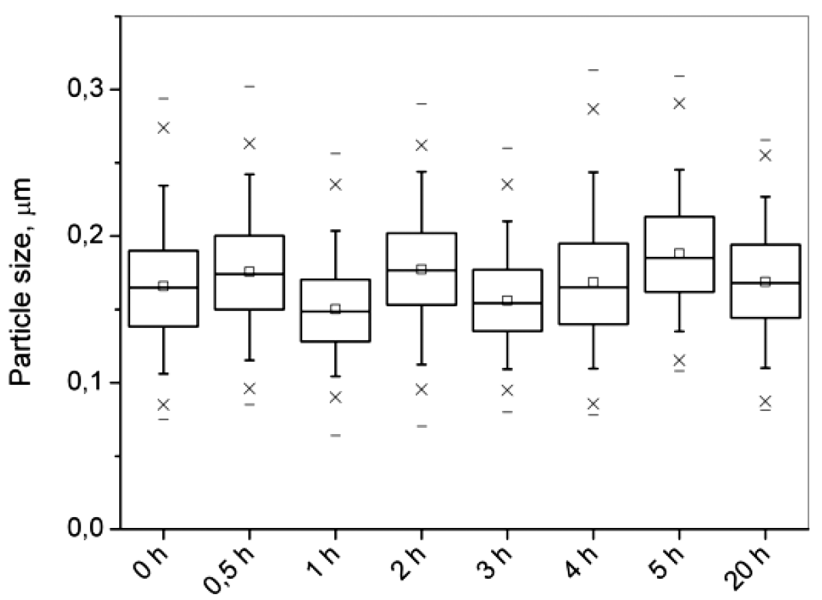

Figure 3: Box charts of the crystal-size distribution of $\mathrm{BaTiO}_{3}$ synthesized in water vapour at $350^{\circ} \mathrm{C}$ and $16 \mathrm{MPa}$ for $0-20 \mathrm{~h}$

Slika 3: Škatlasti diagram razporeditve velikosti kristalnih zrn $\mathrm{BaTiO}_{3}$, sintetiziranih od 0 do 20 ur, v vodni pari pri $350{ }^{\circ} \mathrm{C}$ in $16 \mathrm{MPa}$ 

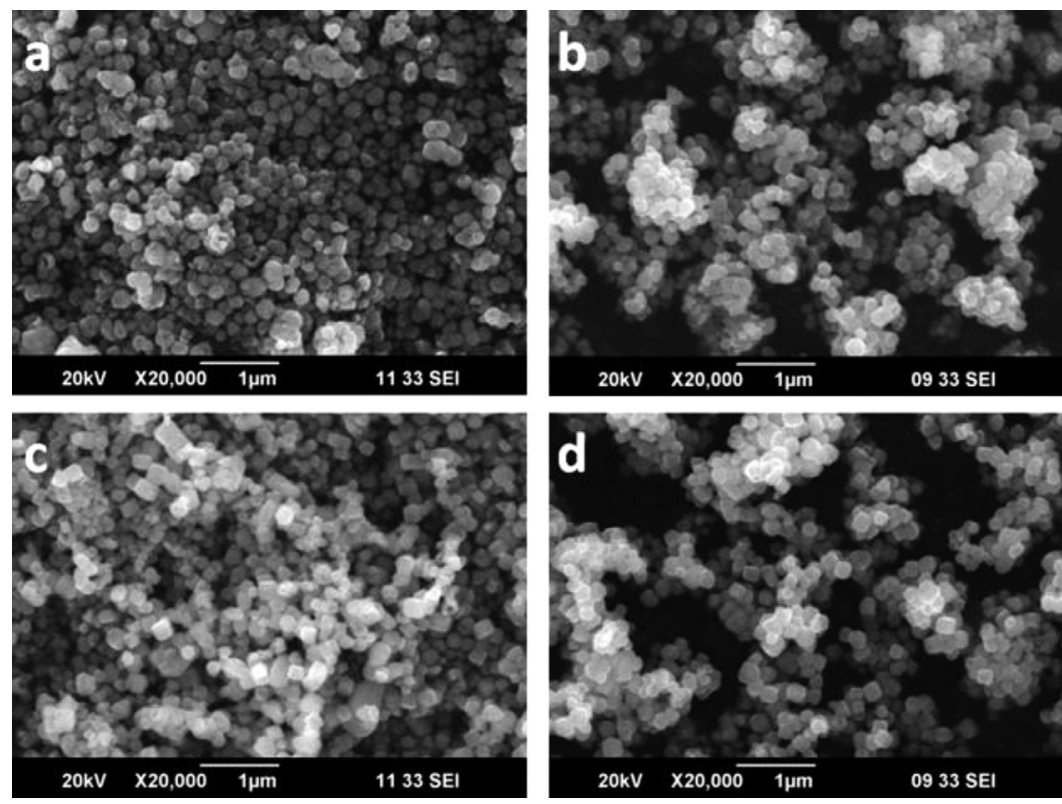

Figure 4: SEM images of $\mathrm{BaTiO}_{3}$ synthesized in water vapour at $350^{\circ} \mathrm{C}$ and $16 \mathrm{MPa}$ for: a) $\left.0 \mathrm{~h}, \mathrm{~b}\right) 3 \mathrm{~h}$, c) $\left.4 \mathrm{~h}, \mathrm{~d}\right) 20 \mathrm{~h}$ Slika 4: SEM posnetki $\mathrm{BaTiO}_{3}$, sintetiziranega v vodni pari pri $350{ }^{\circ} \mathrm{C}$ in $16 \mathrm{MPa}$ po: a) 0 urah, b) 3 urah, c) 4 urah, d) 20 urah

size is reduced. This effect can be explained with the interaction of the excessive amounts of $\mathrm{Ba}(\mathrm{OH})_{2}$ in the reacting mixture with the already formed $\mathrm{BaTiO}_{3}$. It is known that the crystallite size from the Scherrer equation is sensitive to phase inhomogeneities.

In the SEM images of the synthesized samples the crystals of $\mathrm{BaTiO}_{3}$ exhibit a narrow size distribution. The average crystal size slightly varies in a range of $150-188$ $\mathrm{nm}$ without a distinct relation to the duration of the synthesis (Figure 3). There is a clear effect of the reaction time on the shape of the crystals. The samples processed for $0-3 \mathrm{~h}$ consist of sphere-shaped particles (Figures $4 \mathbf{a}$ and $\mathbf{4 b}$ ). A longer processing leads to a

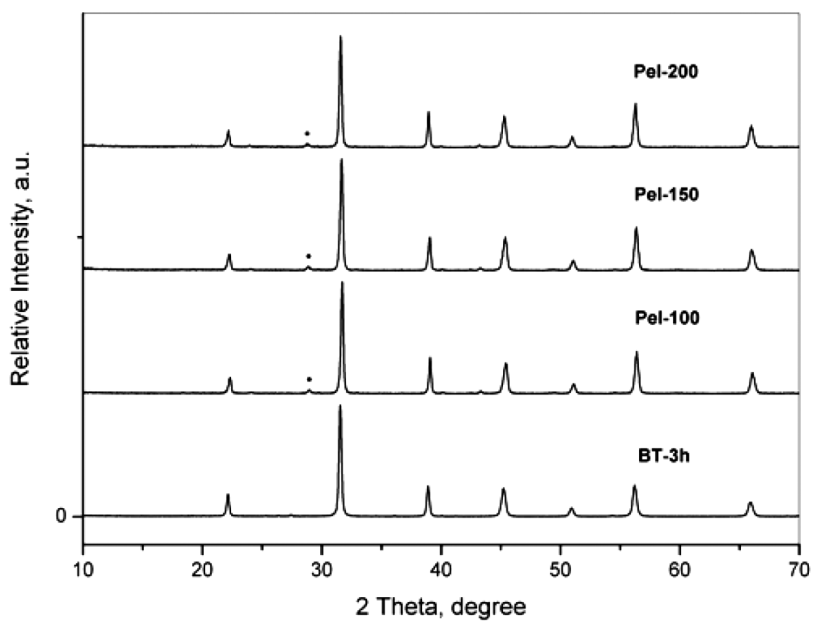

Figure 5: XRD patterns of the $\mathrm{BaTiO}_{3}$ pellets pressed at 100-200 $\mathrm{MPa}$ and sintered at $1300{ }^{\circ} \mathrm{C}$ for $1 \mathrm{~h}$ and $\mathrm{BaTiO}_{3}$ powder $\mathrm{BT} 3 \mathrm{~h}$ used as the raw material

Slika 5: Rentgenogram peletov $\mathrm{BaTiO}_{3}$, stisnjenih pri 100-200 MPa in sintranih 1 uro na $1300{ }^{\circ} \mathrm{C}$ in prah $\mathrm{BaTiO}_{3}$ po 3 urah, uporabljen kot surovina
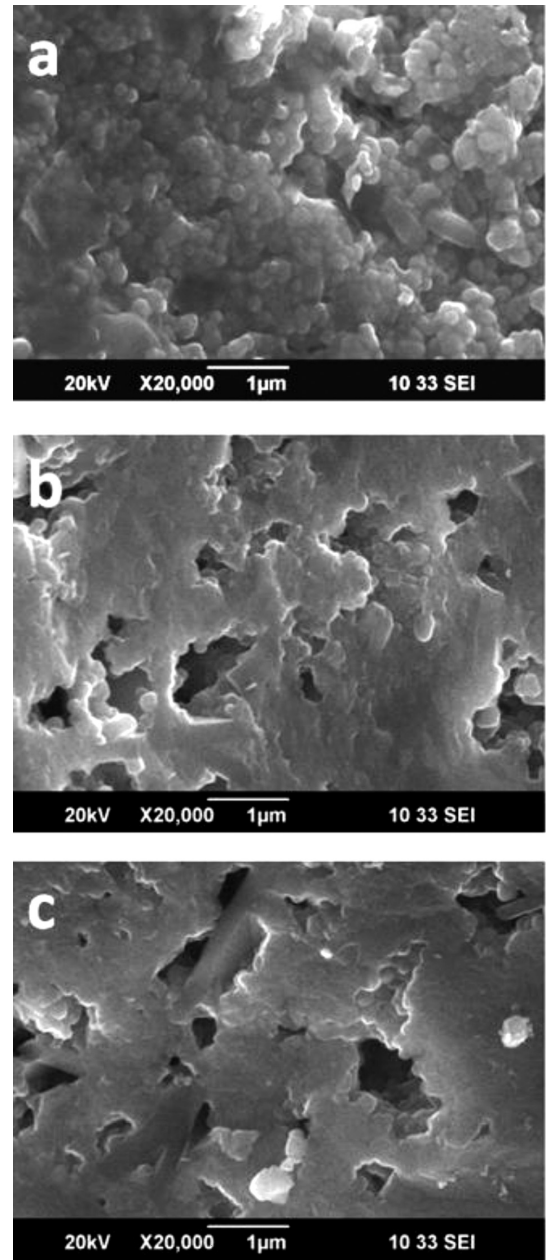

Figure 6: SEM images of the $\mathrm{BaTiO}_{3}$ pellets pressed at: a) $100 \mathrm{MPa}$, b) $150 \mathrm{MPa}$, c) $200 \mathrm{MPa}$, and sintered at $1300^{\circ} \mathrm{C}$ for $1 \mathrm{~h}$

Slika 6: $\mathrm{SEM}$ posnetki $\mathrm{BaTiO}_{3}$ peletov, stisnjenih pri: a) $100 \mathrm{MPa}$, b) $150 \mathrm{MPa}$, c) $200 \mathrm{MPa}$ in sintranih 1 uro na $1300{ }^{\circ} \mathrm{C}$ 


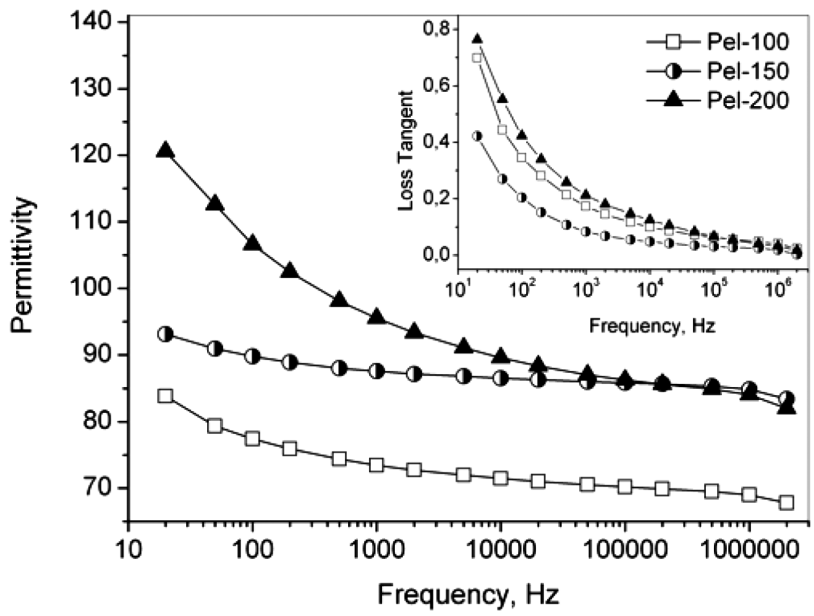

Figure 7: Frequency dependencies of the permittivity and loss tangent of the $\mathrm{BaTiO}_{3}$ ceramic pellets pressed at 100-200 MPa and sintered at $1300{ }^{\circ} \mathrm{C}$ for $1 \mathrm{~h}$

Slika 7: Frekvenčna odvisnost permitivnosti in tangenta izgub $\mathrm{BaTiO}_{3}$ keramičnih peletov, stisnjenih pri 100-200 MPA in sintranih 1 uro na $1300{ }^{\circ} \mathrm{C}$

formation of crystal facets. In the sample synthesized for $4 \mathrm{~h}$ cube-shaped particles could be observed among the sphere-shaped ones and, after $20 \mathrm{~h}$, the sample mainly consisted of faceted crystals (Figures $\mathbf{4 c}$ and $\mathbf{4 d}$ ). The formation of the faceted crystals is related to the $\mathrm{BaTiO}_{3}$ structure perfection due to its interaction with water vapour.

Ceramic pellets were manufactured from the $\mathrm{BaTiO}_{3}$ powder sample synthesized in water vapour for $3 \mathrm{~h}$, so that it consisted of pure, crystalline and sphere-shaped $\mathrm{BaTiO}_{3}$ particles. Three pellets were shaped at different compacting pressures, while the temperature and duration of the sintering were taken from the literature. ${ }^{19-23}$ The geometric density of the pellets was $84-86 \%$ of the theoretical value of $6.01 \mathrm{~g} / \mathrm{cm}^{3}$ (Table 1) and it naturally rose with the increase in the compaction pressure. In addition to the $\mathrm{BaTiO}_{3}$, the XRD analysis showed the presence of an impurity phase in every pellet at $2 \theta=29^{\circ}$ (Figure 5), which is a complex barium aluminate titanate originating from the milling process.

Table 1: Ceramic-processing conditions and density of the pellets Tabela 1: Pogoji pri izdelavi keramike in gostota peletov

\begin{tabular}{|c|c|c|c|c|}
\hline Pellet & $\begin{array}{c}\text { Compacting } \\
\text { pressure, } \\
\mathrm{MPa}\end{array}$ & $\begin{array}{c}\text { Sintering } \\
\text { temperature, } \\
{ }^{\circ} \mathrm{C}\end{array}$ & $\begin{array}{c}\text { Density, } \\
\mathrm{g} / \mathrm{cm}^{3}\end{array}$ & $\begin{array}{c}\text { Relative } \\
\text { density, \% }\end{array}$ \\
\hline Pel-100 & 100 & \multirow{2}{*}{1300} & 5.07 & 84 \\
\hline Pel-150 & 150 & & 5.14 & 86 \\
\hline Pel-200 & 200 & & 5.15 & 86 \\
& & & \\
\hline
\end{tabular}

In the SEM images the pellets consist of the grains of $160-180 \mathrm{~nm}$ in size. Typical features of the pellet microstructure are sub- and micron-sized pores and plates (Figures 6a to $\mathbf{6 c}$ ). The presence of the plates shows that the recrystallization occurred during the sintering and suggests that the temperature of $1300{ }^{\circ} \mathrm{C}$ chosen on the basis of the reference literature is higher than the appropriate sintering temperature for the thermo-vaporous $\mathrm{BaTiO}_{3}$ powder.

The frequency dependence of the dielectric permittivity and loss tangent is shown in Figure 7. The values of both parameters decrease with the increase in the frequency. This phenomenon is common for all dielectrics. The higher the frequency the less polarization can be realized in a dielectric. ${ }^{24}$ As the permittivity is a parameter that shows the polarizability of a dielectric, ${ }^{25}$ it is reduced with a frequency increase. Notably, the permittivity of the pellets shows a strong dependence on the compacting pressure. The permittivity of the pellet manufactured at $150 \mathrm{MPa}$ exhibits the smallest variation in the range of $20 \mathrm{kHz}-2 \mathrm{MHz}$ in comparison with the other two pellets. Both the pellets made at $200 \mathrm{MPa}$ and $100 \mathrm{MPa}$ show a more pronounced variation in the permittivity (Figure 7). The loss tangent shows a similar tendency as the permittivity, depending on the frequency, and the pellet prepared at $150 \mathrm{MPa}$ exhibits the lowest values of $\operatorname{tg} \delta$ among the three examined pellets. Comparing these results, it can be concluded that $150 \mathrm{MPa}$ is the most appropriate compacting pressure for thermovaporous $\mathrm{BaTiO}_{3}$ ceramics.

\section{CONCLUSION}

The present work reports on the results of a thermo-vaporous synthesis and ceramic processing of crystalline $\mathrm{BaTiO}_{3}$. The optimum duration of the synthesis in water vapour at $350{ }^{\circ} \mathrm{C}$ and $16 \mathrm{MPa}$ is $3 \mathrm{~h}$ in order to obtain a raw material for ceramics. The study of the ceramic microstructure showed that the sintering temperature for the thermo-vaporous $\mathrm{BaTiO}_{3}$ powder should be lower than $1300{ }^{\circ} \mathrm{C}$. For the ceramics with the permittivity weakly dependent on the frequency in the range of $20 \mathrm{~Hz}-2 \mathrm{MHz}$ and a low loss tangent, the compacting pressure of $150 \mathrm{MPa}$ involving $1 \% \mathrm{PVA}$ as the binder is the most applicable.

\section{Acknowledgements}

This work was partly supported by the M. V. Lomonosov State University Program of Development. The authors are thankful to Dr. G. P. Muravieva for the help with the XRD analysis and S. A. Chernyak for the SEM study.

\section{REFERENCES}

${ }^{1}$ W. Maison, R. Kleeberg, R. B. Heimann, S. Phanichphant, Phase content, tetragonality and crystallite size of nanoscaled barium titanate synthesized by catecholate process: effect of calcination temperature, J. Eur. Ceram. Soc., 23 (2003) 1, 127-132, doi:10.1016/ S0955-2219(02)00071-7

${ }^{2}$ D. H. Yoon, B. I. Lee, Processing of barium titanate tapes with different binders for MLCC applications - Part I: Optimization using design of experiments, J. Eur. Ceram. Soc., 24 (2004) 5, 739-752, doi:10.1016/S0955-2219(03)00333-9 
${ }^{3}$ U. A. Joshi, S. Yoon, S. Baik, J. S. Lee, Surfactant-free hydrothermal synthesis of highly tetragonal barium titanate nanowires: a structural investigation, J. Phys. Chem. B., 110 (2006), 12249-12256, doi:10.1021/jp0600110

${ }^{4}$ D. Padalia, G. Bisht, U. C. Johri, K. Asokan, Fabrication and characterization of cerium doped barium titanate/PMMA nanocomposites, Solid State Sciences, 19 (2013), 122-129, doi:10.1016/ j.solidstatesciences.2013.02.002

${ }^{5}$ Ch. Pithan, D. Hennings, R. Waser, Progress in synthesis of nanocrystalline $\mathrm{BaTiO}_{3}$ powders for MLCC, Int. J. Appl. Ceram. Technol., 2 (2005) 1, 1-14, doi:10.1111/j.1744-7402.2005.02008.x

${ }^{6} \mathrm{D}$. H. Yoon, Tetragonality of barium titanate powder for ceramic capacitor application, Journal of Ceramic Processing Research, 7 (2006) 4, 343-354

${ }^{7}$ W. S. Jung, J. H. Kim, H. T. Kim, D. H. Yoon, Effect of temperature schedule on the particle size of barium titanate during solid-state reaction, Materials Letters, 64 (2010) 2, 170-172, doi:10.1016/ j.matlet.2009.10.035

${ }^{8}$ V. Vinithini, P. Singh, M. Balasubramanian, Synthesis of barium titanate nanopowder using polymeric precursor method, Ceramics International, 32 (2006) 2, 99-103, doi:10.1016/j.ceramint.2004. 12.012

${ }^{9}$ P. Duran, F. Capel, J. Tartaj, D. Gutierrez, C. Moure, Heating-rate effect on the $\mathrm{BaTiO}_{3}$ formation by thermal decomposition of metal citrate polymeric precursors, Solid State Ionics, 141-142 (2001), 529-539, doi:10.1016/S0167-2738(01)00742-1

${ }^{10}$ A. Purwanto, W. N. Wang, I. W. Lenggoro, K. Okuyama, Formation of $\mathrm{BaTiO}_{3}$ nanoparticles from an aqueous precursor by flameassisted spray pyrolysis, J. Eur. Ceram. Soc., 27 (2007) 16, 4489-4497, doi:10.1016/j.jeurceramsoc.2007.04.009

${ }^{11}$ M. R. Mohammadi, D. J. Fray, Sol-gel derived nanocrystalline and mesoporous barium strontium titanate prepared at room temperature, Particuology, 9 (2011) 3, 235-242, doi:10.1016/j.partic.2010.08.012

${ }^{12}$ Y. B. Khollam, A. S. Deshpande, H. S. Potdar, S. B. Deshpande, S. K. Date, A. J. Patil, A self-sustaining acid-base reaction in semiaqueous media for synthesis of barium titanyl oxalate leading to $\mathrm{BaTiO}_{3}$ powders, Materials Letters, 55 (2002) 3, 175-181, doi:10.1016/S0167-577X(01)00642-5

${ }^{13}$ K. Y. Chen, Y. W. Chen, Preparation of barium titanate ultrafine particles from rutile titania by a hydrothermal conversion, Powder Technology, 141 (2004) 1-2, 69-74, doi:10.1016/j.powtec.2004. 03.002
${ }^{14}$ S. G. Kwon, K. Choi, B. I. Kim, Solvothermal synthesis of nanosized tetragonal barium titanate powders, Materials Letters, 60 (2006) 7, 979-982, doi:10.1016/j.matlet.2005.10.089

${ }^{15}$ M. N. Danchevskaya, Yu. D. Ivakin, S. N. Torbin, G. P. Muravieva, O. G. Ovchinnikova, Thermovaporous synthesis of complicated oxides, J. Mater. Sci., 41 (2006) 5, 1385-1390, doi:10.1007/s10853006-7411-0

${ }^{16}$ Yu. D. Ivakin, M. N. Danchevskaya, G. P. Muravieva, Kinetic model and mechanism of $\mathrm{Y}_{3} \mathrm{Al}_{5} \mathrm{O}_{12}$ formation in hydrothermal and thermovaporous synthesis, High Pressure Research, 20 (2001) 1-6, 87-98, doi:10.1080/08957950108206156

${ }^{17}$ A. A. Kholodkova, M. N. Danchevskaya, A. S. Fionov, Investigation of fine-crystalline barium titanate synthesized in water fluid, Abstr. of the XIV Inter. Scientific Conf. High-Tech in Chemical Engineering, Tula, 2012, 547

${ }^{18}$ A. A. Kholodkova, M. N. Danchevskaya, A. S. Fionov, Study of nanocrystalline barium titanate formation in water vapour conditions, Proc. of the 4th Inter. Conf. NANOCON 2012, Brno, 2012, 66-71

${ }^{19}$ W. Cai, C. Fu, Z. Lin, X. Deng, Vanadium doping effect on microstructure and dielectric properties of barium titanate ceramics, Ceramics International, 37 (2011), 3643-3650, doi:10.1016/ j.ceramint.2011.06.024

${ }^{20}$ M. M. Vijatovic Petrovic, J. D. Bobic, T. Ramoska, B. D. Stojanovic, Electrical properties of lanthanum doped barium titanate ceramics, Materials Characterization, 62 (2011), 1000-1006, doi:10.1016/ j.matchar.2011.07.013

${ }^{21}$ P. Kumar, S. Singh, M. Spah, J. K. Juneja, Ch. Pracash, K. K. Raina, Synthesis and dielectric properties of substituted barium titanate ceramics, J. of Alloys and Compounds, 489 (2010), 59-63, doi:10.1016/j.jallcom.2009.08.024

${ }^{22}$ S. B. Narang, D. Kaur, Sh. Bahel, Dielectric properties of lanthanum substituted barium titanate microwave ceramics, Materials Letters, 60 (2006), 3179-3182, doi:10.1016/j.matlet.2006.02.079

${ }^{23}$ L. J. Gao, X. L. Liu, J. Q. Zhang, S. Q. Wang, J. F. Chen, Graincontrolled barium titanate ceramics prepared from high-gravity reactive precipitation process powder, Materials Chemistry and Physics, 88 (2004), 27-31, doi:10.1016/j.matchemphys.2004.03.023

${ }^{24}$ T. Lee, I. A. Aksay, Hierarchical structure-ferroelectricity relationship of barium titanate particles, Crystal Growth \& Design, 1 (2001) 5, 401-419, doi:10.1021/cg010012b

${ }^{25}$ B. M. Yavorskiy, A. A. Detlaf, Spravochnik po fizike, Nauka, Moscow 1974 